\title{
Alkali- and Cl-enriched carbonate-silicate melt inclusions in sheared lherzolite xenoliths from unaltered kimberlites of the Udachnaya- East pipe (Yakutia)
}

\author{
Alexander V. Golovin ${ }^{1}$, Igor S. Sharygin ${ }^{1}$, Andrey V. Korsakov ${ }^{1}$, Vadim S. Kamenetsky ${ }^{2}$, \\ and Nikolai P. Pokhilenko ${ }^{1}$ \\ ${ }^{1}$ Institute of Geology and Mineralogy, Novosibirsk, Russia \\ ${ }^{2}$ CODES and School of Earth Sciences, University of Tasmania, Hobart, TAS, Australia
}

Introduction. Mantle xenoliths worldwide may contain significant amount of fluid, melt and mineral phases that were introduced into and between rockforming minerals at some later stage(s). Such secondary inclusions and interstitial assemblages can be important in deciphering compositions of the mantle-derived melts and fluids and their role in modifying mantle rocks in situ and during transport to the surface. Previous studies of melt inclusions in the minerals of mantle xenoliths, carried by basaltic magmas, revealed their dominantly silicate glass composition (Andersen and Neumann, 2001; Schiano and Clocchiatti, 1994). On the other hand, the existing data on melt inclusions from the kimberlite-hosted mantle xenoliths are very scarce, and the trapping mechanism of inclusions described is controversial (van Achterbergh et al., 2004). Here we present first results on the "classical" melt inclusions in sheared lherzolite xenoliths from kimberlites.

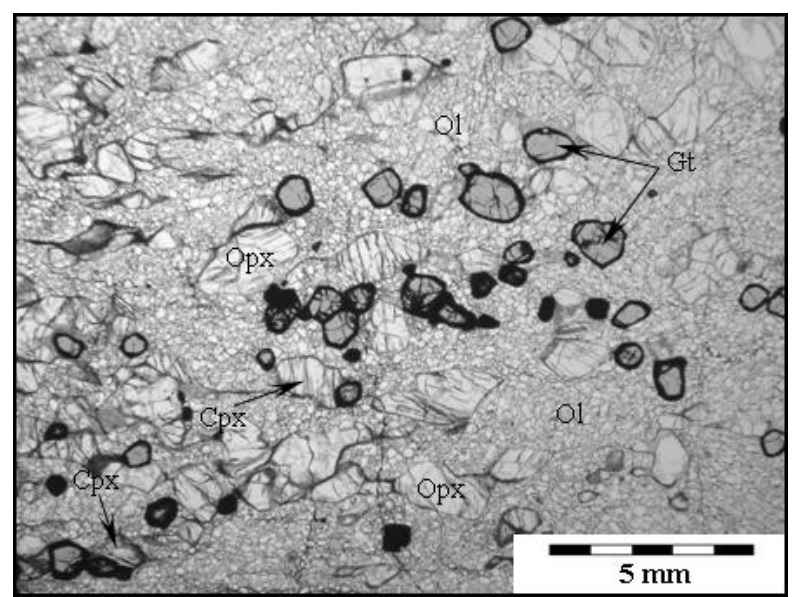

Fig. 1. Plain-polarized light photomicrograph of the thin section of the sheared lherzolite xenolith with mosaic-porphyroclastic texture from the UdachnayaEast pipe kimberlite. Ol - olivine, Opx orthopyroxene, $\mathrm{Cpx}$ - clinopyroxene, $\mathrm{Gt}$ - garnet.

Xenoliths of sheared lherzolites are possibly the deepest mantle samples available, and believed to originate from the lithosphere - astenosphere boundary, which is present at different depths beneath different kimberlite pipes (Boyd and Gurney, 1986). Their texture is defined by chain-like assemblages of garnet, pyroxenes and olivine porphyroclasts in a matrix of fine-grained recrystallized (neoblastic) olivine (Fig. 1). Origin of such textures is still debatable, and in general assigned to several shear deformation events. Our twenty samples of sheared lherzolites in the unaltered Udachnaya-East kimberlites (Yakutia, Russia) show a primary assemblage of olivine, orthopyroxene, clinopyroxene and garnet that were equilibrated at $61-74 \mathrm{~kb}$ and $1230-1370^{\circ} \mathrm{C}$ (according to a geothermobarometer of Brey and Kohler, 1990), as well as interstitial fine-grained aggregates and widespread melt inclusions in primary minerals.

Melt inclusions. Melt inclusions are present in all primary minerals of lherzolites, including both porphyroclasts and neoblasts of olivine, and thus attest to their trapping after rock deformation. Melt inclusions of variable sizes and shapes are hosted in healed fractures, some of which transect entire grains of host minerals (Fig. 2), and therefore are secondary in origin.

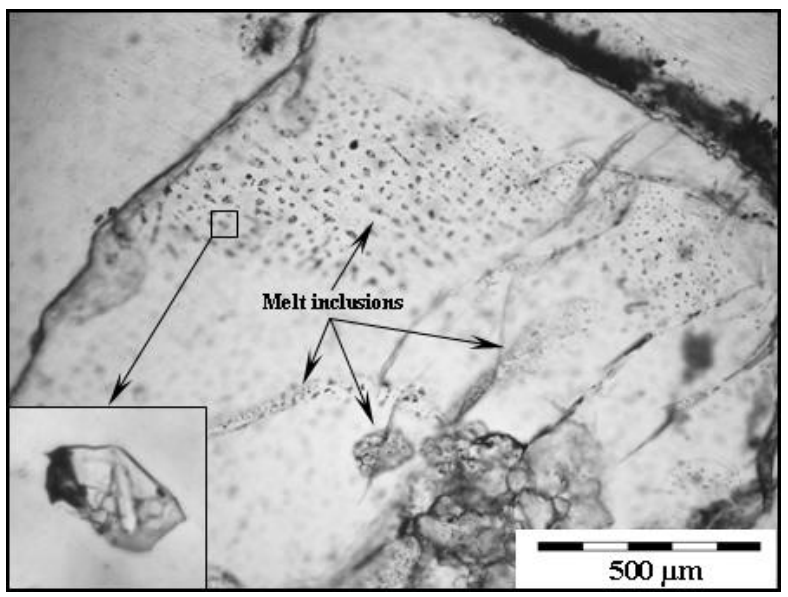

Fig. 2. Swarms and trails of secondary melt inclusion in olivine in sheared lhezolite xenoliths from the Udachnaya-East pipe. 
The melt inclusions are variable in shape from irregular to ovoid and drop-like. They consist of fine-grained

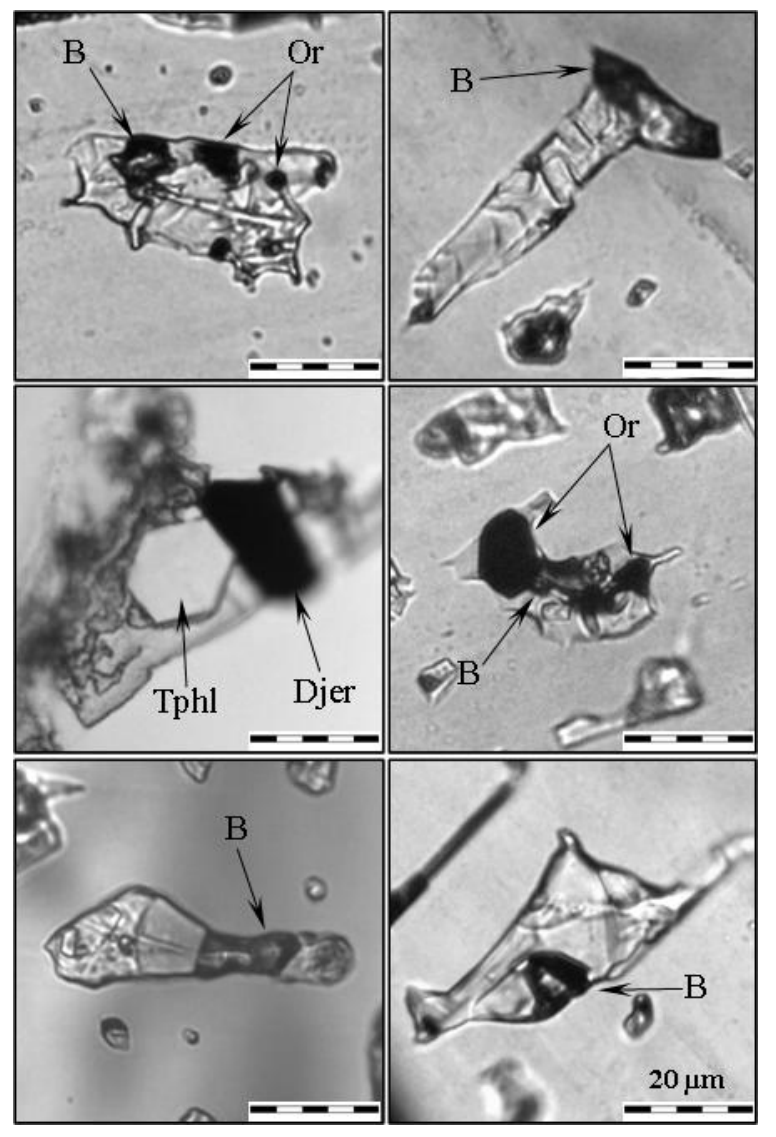

Fig. 3. Individual melt inclusions in olivine from sheared lhezolite xenoliths from the Udachnaya-East pipe. Daughter phases: B - bubble, Tphl tetraferriphlogopite, Or - opaque phase, Djer djerfisherite. Scale bar is $20 \mu \mathrm{m}$

aggregate of carbonates, sulphates and chlorides, some translucent crystals, opaque minerals (magnetite, djerfisherite, pentlandite, pyrrhotite) and a vapour bubble (Fig. 3, 4). Daughter crystals (up to twenty in individual inclusions) are represented by silicates (tetraferriphlogopite, olivine), chlorides (halite, sylvite) and various carbonates, sulphates and sulphides that were recognised with the laser Raman spectroscopy. Unfortunately, the existing database of Raman spectra for rare alkali-bearing carbonates and sulphates is incomplete; nevertheless, the following minerals are likely present: carbonates - calcite $\mathrm{CaCO}_{3}$ (band at 1084-1088 $\left.\mathrm{cm}^{-1}\right)$, dolomite $\mathrm{CaMg}\left(\mathrm{CO}_{3}\right)_{2}$ (1094-1099 $\left.\mathrm{cm}^{-1}\right)$, gregoryite $\left(\mathrm{Na}_{2}, \mathrm{~K}_{2}, \mathrm{Ca}\right) \mathrm{CO}_{3}\left(1077-1079 \mathrm{~cm}^{-1}\right)$, shortite $\mathrm{Na}_{2} \mathrm{Ca}_{2}\left(\mathrm{CO}_{3}\right)_{3}$ and/or zemkorite $(\mathrm{Na}, \mathrm{K})_{2} \mathrm{Ca}\left(\mathrm{CO}_{3}\right)_{2} \quad\left(1069-1072 \mathrm{~cm}^{-1}\right.$ and 1084-1092 $\left.\mathrm{cm}^{-1}\right)$, nyerereite $\mathrm{Na}_{2} \mathrm{Ca}\left(\mathrm{CO}_{3}\right)_{2} \quad\left(1088-1089 \mathrm{~cm}^{-1}\right)$, northupite $\quad \mathrm{Na}_{3} \mathrm{Mg}\left(\mathrm{CO}_{3}\right)_{2} \mathrm{Cl} \quad\left(1114-1116 \quad \mathrm{~cm}^{-1}\right)$; compound sulphate-carbonate burkeite $\mathrm{Na}_{4} \mathrm{SO}_{4} \mathrm{CO}_{3}$ (bands at 994 и $1065 \mathrm{~cm}^{-1}$ ); sulphates - aphthtitalite $\mathrm{K}_{3} \mathrm{Na}\left(\mathrm{SO}_{4}\right)_{2}$ (992 и $\left.1082 \mathrm{~cm}^{-1}\right)$, glauberite $\mathrm{Na}_{2} \mathrm{Ca}\left(\mathrm{SO}_{4}\right)_{2}$ (1000-1002 $\left.\mathrm{cm}^{-1}\right)$ and/or thenardite $\mathrm{Na}_{2} \mathrm{SO}_{4}$ (992-994 $\left.\mathrm{cm}^{-1}\right)$, and possibly schairerite $\mathrm{Na}_{21}\left(\mathrm{SO}_{4}\right)_{7} \mathrm{~F}_{6} \mathrm{Cl}(999$ $\mathrm{cm}^{-1}$ ) (Fig. 3, 4). Identification of all daughter minerals, especially those with a submicron size, was not always possible, and this made estimates of the bulk inclusion compositions problematic. In general, main phases are $\mathrm{Ca}-$, Na- and K-bearing carbonates, chlorides and sulphates, whereas silicate minerals occupy $<15$ vol $\%$ of the inclusion volume. Thus, these inclusions are similar to those in carbonatites and associated alkaline silicate rocks (Panina and Motorina, 2008). The content of the melt inclusions homogenises at $700-780{ }^{\circ} \mathrm{C}$.

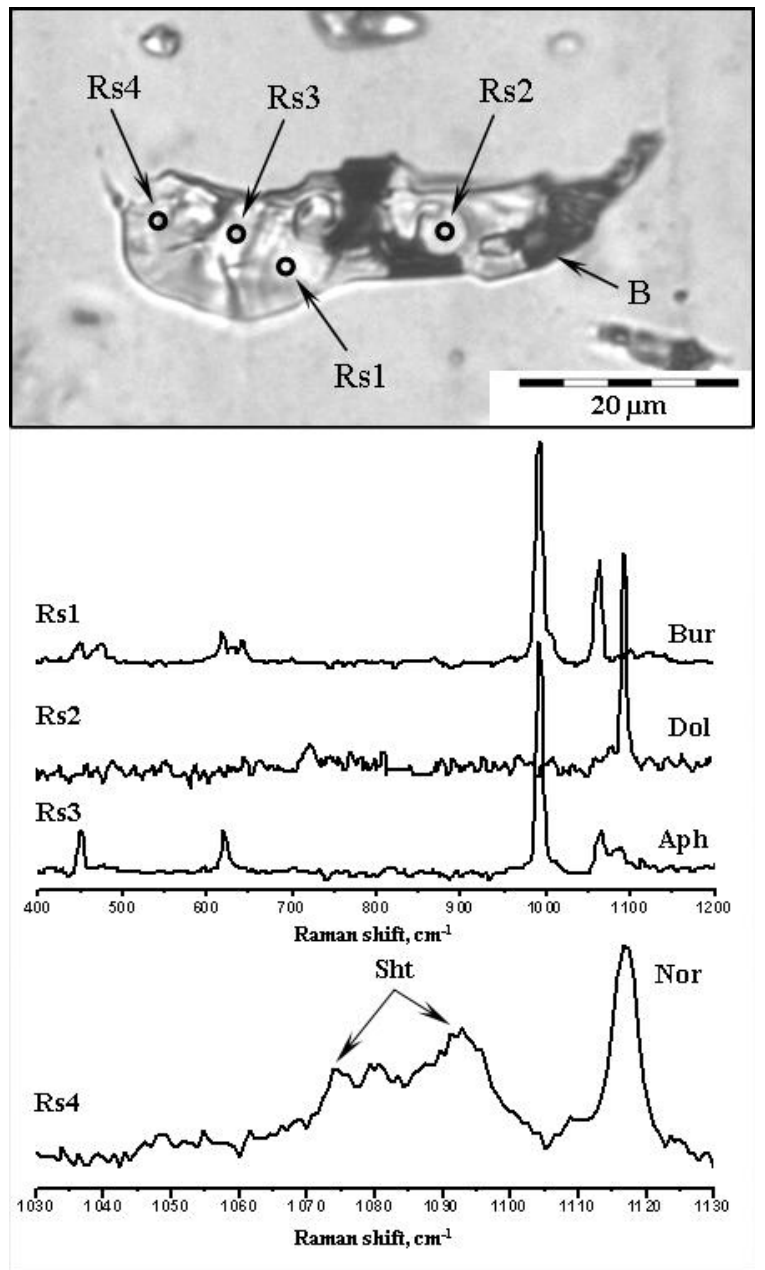

Fig. 4. Raman spectra (Rs1-4) of some daughter phases in the secondary melt inclusion in olivine from a sheared lhezolites xenolith. Phases: B - bubble, Bur burkeite, Dol - dolomite, Aph - aphtitalite, Nor northupite, Sht - shortite.

Discussion. Secondary melt inclusions in mantle xenoliths are traditionally related to migrating mantle liquids/fluids, not necessarily genetically linked to the magmas transporting xenoliths (Andersen and Neumann, 2001; Schiano and Clocchiatti, 1994). Although "metasomatic" and "in-situ melting" events in the origin of these inclusions at unknown depths and times cannot be completely excluded, we are intrigued by their similarity to melt inclusions hosted in the kimberlitic olivine of the Udachnaya-East pipe (Golovin et al., 2003; 2007; Kamenetsky et al., 2004; Sharygin et al., 2007). We note striking resemblance in the composition of daughter phases and temperatures of homogenisation, and thus the relationship between 
the melt entrapped in xenoliths and kimberlite magma is most probable. We envisage trapping of the host kimberlite melt in the minerals of xenoliths as they are mechanically fractured on decompression, corroded and recrystallised en route to the surface. Application of the compositional signature of melt inclusions to deciphering true nature of the kimberlite magma entails a silicate-carbonate melt composition enriched in alkalies, chlorine and sulphur, and evolving towards an essentially carbonatite-chloride, alkali-rich liquid. Significant amount of alkali- and chlorine-bearing daughter minerals in the melt inclusions is inconsistent with the idea of platform brines affecting the groundmass of the unaltered Udachnaya-East kimberlites.

On the other hand, the melt inclusions if trapped in the minerals of lherzolite xenoliths at mantle depths, could represent products of metasomatic reactions between mantle rocks and protokimberlite liquids. This is supported by studies of olivine microphenocrysts in the Udachnaya-East kimberlite that have resorbed cores with compositions typical of mantle olivine (Kamenetsky et al., 2008). Resorption and dissolution of xenogenic olivine and orthopyroxene in the kimberlite melt should enrich the latter in $\mathrm{SiO}_{2}$ and $\mathrm{MgO}$. Therefore, reconstruction of compositions of primary/parental melts for any given kimberlite should take into account evolutionary history of olivine phenocrysts (core-rim compositional and volumetric proportions) and effects of dissolution of mantle minerals on the original alkali carbonate-chloride composition.

In conclusion, whatever the origin (deep mantle or near-surface) and trapping mechanism of the studied melt inclusions, their compositions unambiguously point to high concentrations of alkalies, carbon, chlorine and sulphur in the mantle melts originated at the lithosphere - astenosphere boundary. This first finding of relict alkali-carbonate liquids in the kimberlite-hosted mantle nodules can put further constraints on a kimberlite-carbonatite lineage.
This work is funded by the Russian Foundation of Basic Research grants № 07-05-00072 and MK2138.2007.5.

\section{References}

Andersen, T. and Neumann, E.-R., 2001. Fluid inclusions in mantle xenoliths. Lithos, 55: 301-320.

Boyd, F.R. and Gurney, J.J., 1986. Diamonds and the African lithosphere. Science, 232: 472-477.

Brey, G.P. and Kohler, T., 1990. Geothermobarometry in four phase lherzolites II. New thermobarometers and practical assessment of existing thermobarometers. Journal of Petrology, 31: 1353-1378.

Golovin, A.V. et al., 2003. Secondary melt inclusions in olivine from unaltered kimberlites of the Udachnaya-East pipe, Yakutia. Doklady Earth Sciences, 388: 93-96.

Golovin, A.V., Sharygin, V.V. and Pokhilenko, N.P., 2007. Melt inclusions in olivine phenocrysts in unaltered kimberlites from the Udachnaya-East pipe, Yakutia: Some aspects of kimberlite magma evolution during late crystallization stages. Petrology, 15(2): 168-183.

Kamenetsky, M.B. et al., 2004. Kimberlite melts rich in alkali chlorides and carbonates: a potent metasomatic agent in the mantle. Geology, 32(10): 845-848.

Kamenetsky, V.S. et al., 2008. Olivine in the Udachnaya-East kimberlite (Yakutia, Russia): types, compositions and origins. Journal of Petrology, 49: 823-839.

Panina, L.I. and Motorina, I.V., 2008. Liquid immiscibility in deeply derived magmas and the origin of carbonatite melts. Geochemistry International, 46: 448-464.

Schiano, P. and Clocchiatti, R., 1994. Worldwide occurence of silica-rich melts in sub-continental and suboceanic mantle minerals. Nature, 368: 621-624.

Sharygin, V.V., Golovin, A.V., Pokhilenko, N.P. and Kamenetsky, V.S., 2007. Djerfisherite in the Udachnaya-East pipe kimberlites (Sakha-Yakutia, Russia): paragenesis, composition and origin. European Journal of Mineralogy, 19: 51-63.

van Achterbergh, E. et al., 2004. Melt inclusions from the deep Slave lithosphere: implications for the origin and evolution of mantle-derived carbonatite and kimberlite. Lithos, 76(1-4): 461-474. 